\title{
Deklaracja zgodności WE dla maszyny - niebezpieczna rzeczywistość
}

\section{Declaration of conformity for machine - dangerous reality}

\section{Streszczenie}

W opracowaniu przedstawiono luki w zapisach Dyrektywy Maszynowej, jako wynik bardzo negatywnej ekspertyzy elementu konstrukcyjnego linii technologicznej przetwórstwa spożywczego. Przedstawiono również propozycje zapewnienia sobie przez zamawiającego akceptowalnego poziomu jakości konstrukcji w istniejącej sytuacji.

Słowa kluczowe: deklaracja maszynowa; zapewnienie jakości wyrobu; wymagania jakościowe; dokumentacja zdawcza

\begin{abstract}
The article presents regulations or gap in regulations regarding welding in Machinery Directive 2006/42/EC. The base of the article were tests and analysis of destroyed construction part of transportation line in food industry. The way to ensure right quality of welding structures are presented.
\end{abstract}

Keywords: declaration of conformity (machine); providing the product quality; quality requirements; quality records

\section{Wstęp}

Kraje Wspólnoty wprowadziły dyrektywę maszynową [1], albowiem: „Sektor maszynowy jest ważną gałęzią przemysłu inżynieryjnego i stanowi jeden z przemysłowych filarów gospodarki Wspólnoty. Koszty społeczne dużej liczby wypadków powodowanych bezpośrednio przez użytkowanie maszyn można zmniejszyć przez projektowania i wykonanie maszyn bezpiecznych z samego założenia oraz przez właściwe ich instalowanie i konserwację" [1]. Rzeczona dyrektywa, nie stawia niestety żadnych wymagań procesom spawalniczym. W jej obszarze nie funkcjonuje odpowiednik serii norm EN 1090 [2], która w sektorze budownictwa zdecydowanie podniosła poziom jakości, również w małych firmach [5] i nie przywołuje norm serii EN 3834 [3,4], w wielu segmentach przemysłowych wręcz obligatoryjnej. Stan taki sprzyja sytuacjom patologicznym opisanym już w literaturze fachowej $[6,7]$ i jest daleki od praktyki w segmencie okrętowym $[8,9]$ i offshore $[10,11]$ znanych ze znakomitego poziomu spawalnictwa i wymagań określonych w opracowaniu [12].

Przy takim stanie przepisów, rzeczywistość bywa brutalna. Przekonała się o tym pewna polska firma branży spożywczej, eksploatująca linię technologiczną wykonaną przez Wytwórcę z Holandii, w świetle załączonych dokumentów, zgodnie z rzeczoną dyrektywą (deklaracja zgodności we dla maszyny, ze znakiem CE), gdy nastąpiła jej awaria. Awarii uległ "łuk 180", stanowiący konstrukcję obudowy napędu łańcuchowego owej linii (ważący ok. 20 kg), który po prostu spadł na ziemię i rozleciał się na dwie części (rys. 1).
Prawdopodobną przyczyną awarii było lokalne szarpnięcie nieco poluzowanego łańcucha napędu - co wynika z samej istoty rzeczonego napędu, bowiem w czasie eksploatacji następuje nierównomierne wydłużenie owego łańcucha w przedziale 1,3 do 6,6 mm na 1 mb, przekraczające możliwości napinaczy. Takie zjawisko wskazuje, że siły rozciągające mogą nawet przekraczać granicę plastyczności, więc mogą być na poziomie do $57 \mathrm{kN}$. Z prostej analizy sił jasno wynika, że przy poprawnie wykonanych spoinach nie doszłoby do awarii.

Ciekawe było też podejście Wytwórcy, który mimo, że "maszyna" była na gwarancji, nie widział w tym wydarzeniu swojej winy. Co prawda, przyznał, że złącza spawane nie spełniają wymogów EN 5817, ale oficjalnie głosił, że spoiny spełniają ich wewnętrzne standardy wytrzymałościowe!

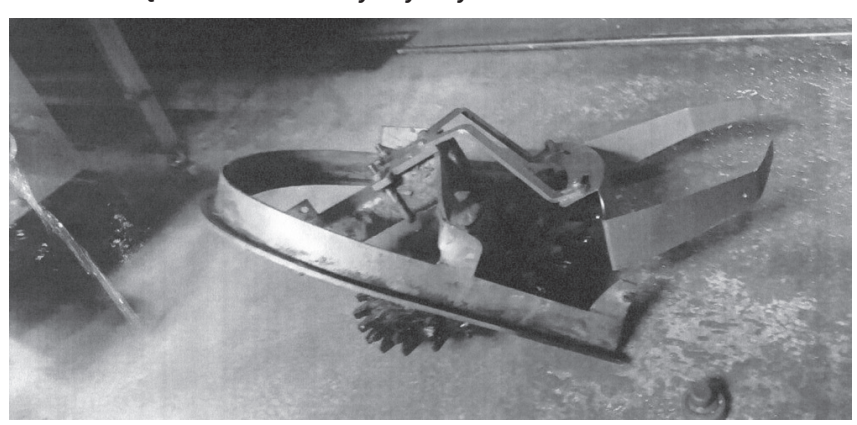

Rys. 1. Uszkodzona konstrukcja w wyniku awarii konstrukcji łuku Fig. 1. The destroyed structure after breakdown

Mgr inż. Marek Saperski - Biuro Techniki Spawalniczej „BM”.

Autor korespondencyjny/Corresponding author. biuro@saperski.com.pl 
W wyniku uporu Wytwórcy, godnego lepszej sprawy, powstała rzeczona ekspertyza, obnażająca tragicznie niski poziom złączy spawanych. A jej angielska wersja językowa, stała się głównym dowodem w sprawie, już na szczeblu zarządu sporego, niemieckiego koncernu, którego częścią jest polska przetwórnia, w której nastąpiła rzeczona awaria. I tym sposobem sprawa beznadziejnej jakości połączeń spawanych została upubliczniona na najwyższym szczeblu decyzyjnym. Wytwórca musiał skapitulować i zgodzić się na ciężkie warunki zadośćuczynienia, tracąc zdecydowanie na wizerunku i wiarygodności, a w przyszłości może nawet ważnego klienta. Jak widać nie zawsze opłaca się iść w zaparte!

\section{Konstrukcja linii technologicznej}

W największym skrócie owa linia technologiczna składa się z prowadnic, po których przemieszczają się wagoniki, do których podczepiane są przetwarzane produkty. Ruch wagoników zapewnia łańcuch napędzany kołami łańcuchowymi, umieszczonymi w rzeczonym łuku $180^{\circ}$. Linia ma długość rzędu 6 km i składa się z odcinków (wynikających z rozmiarów hal produkcyjnych) długości w przedziale 50 $\div 170 \mathrm{~m}$, a na obu końcach takiego odcinka znajduje się rzeczony "tuk", których w sumie jest blisko 100 szt. Linia jest zawieszona pod sufitem, na wysokości rzędu $2 \div 4 \mathrm{~m}$ od podłogi, a pod nią pracują ludzie. Tylko przypadek sprawił, że upadek konstrukcji łuku nie spowodował groźnego w skutkach wypadku.

\section{Konstrukcja obudowy napędu łańcuchowego (łuku 180}

Konstrukcję obudowy przedstawiono na rysunku 2. Jak widać, jest ona spawana i składa się z blach i kształtowników o grubości $6 \div 7 \mathrm{~mm}$. W wyniku awarii została zniszczona część złączy spawanych, a pozostałe dały się łatwo połamać przez przeginanie ręką. Rozmieszczenie spoin łuku pokazano na rysunku 3 , a na rysunkach $4 \div 6$ pokazano przykładowe przełomy tych złączy.

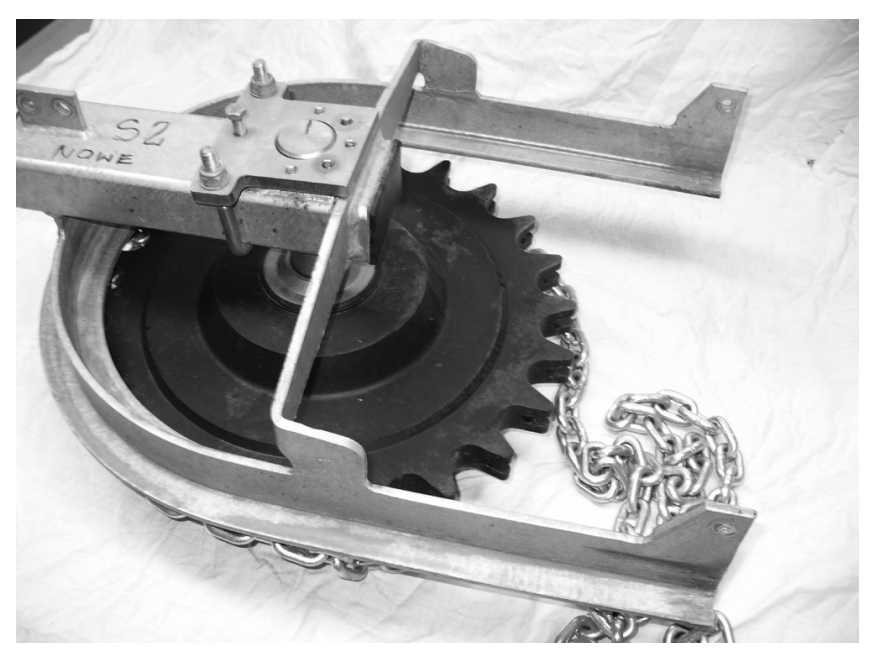

Rys. 2. Konstrukcja obudowy napędu łańcuchowego (łuku)

Fig. 2. The structure of cover of a chain wheel

\section{Badania laboratoryjne złączy spawanych fuku $180^{\circ}$}

Złącza zniszczone w wyniku awarii (lub złamane ręką) rysunki $3 \div 6$, poddano badaniom wizualnym (VT). Natomiast złącza niezniszczone, pochodzące z identycznych dwóch łuków nieuszkodzonych (dla większego obiektywizmu wyników) poddano badaniom: RT, makroskopowym i próbie rozciągania. Wszystkie badania zostały wykonane przez niezależne i autoryzowane laboratoria.

\section{Wyniki badań laboratoryjnych}

1. Badania VT - wszystkie złącza wykazały brak przetopu po niżej poziomu D wg EN ISO 5817.

2. Badania RT - wszystkie złącza wykazały niezgodności poniżej poziomu D wg EN ISO 5817.

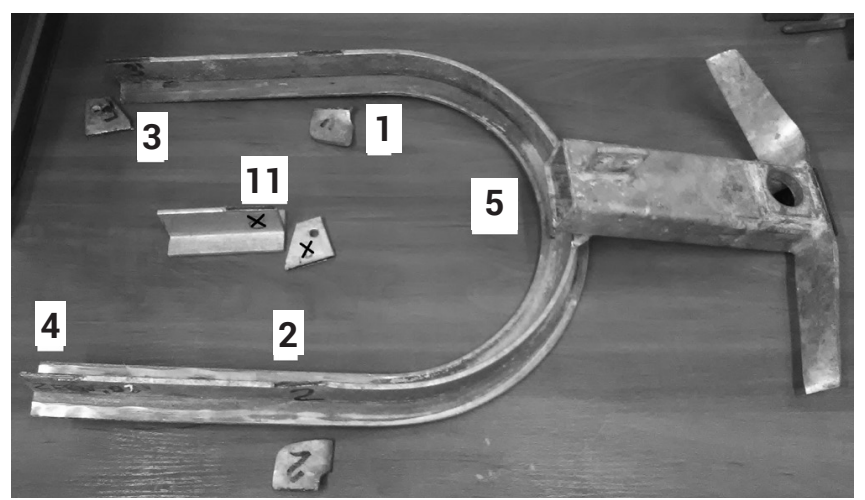

Rys. 3. Umiejscowienie badanych spoin na łuku

Fig. 3. Overall test-piece setup

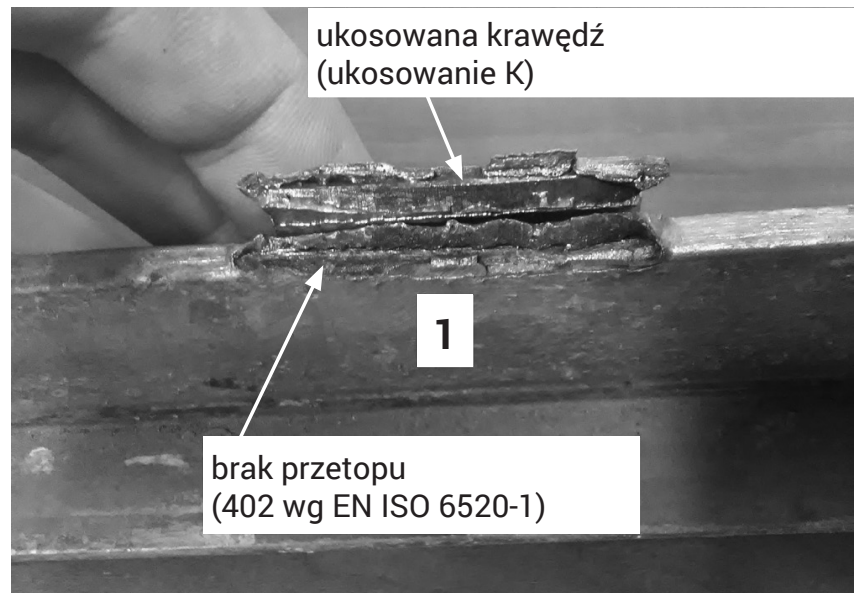

Rys. 4. Przełom złącza $\mathrm{nr} 1$, ukosowanie na K, brak przetopu 402 wg EN ISO 6520-1

Fig. 4. Fracture no. 1 (K-grove, lack of penetration 402 acc. to EN ISO 6520-1)

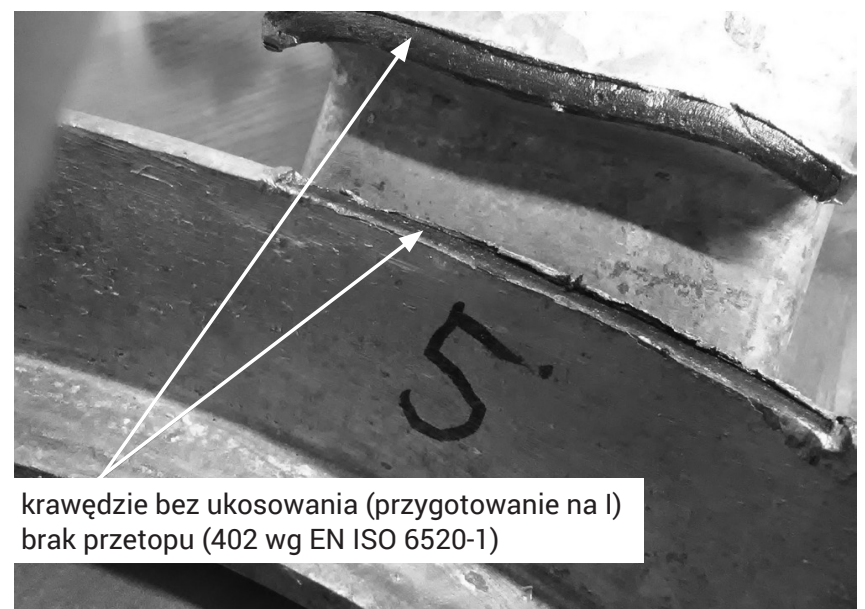

Rys. 5. Przełom złącza nr 5, ukosowanie I, brak przetopu $402 \mathrm{wg}$ EN ISO 6520-1

Fig. 5. Fracture no. 5 (I-grove, lack of penetration 402 acc. to EN ISO 6520-1) 
3. Badania makroskopowe - wszystkie złącza wykazały nieakceptowalne niezgodności. Przykładowe zgłady pokazano na rysunkach $7 \div 9$.

4. Badania wytrzymałościowe - próba rozciągania - wyniki tych badań przedstawiono w tablicy I. Jak widać wytrzymałość złączy "oryginalnych" mieści się w przedziale $72 \div 295 \mathrm{MPa}$, a jednocześnie złącze poprawne (nr 51), naprawione przez użytkownika linii, uzyskało wytrzymałość $496 \mathrm{MPa}$, więc wytrzymałość złączy "oryginalnych" wynosi 14,5 $\div 59,3 \%$ jego wartości, a średnia 218,5 MPa. (czyli 44\% wartości nominalnej). Jak widać, konstrukcja jest wykonana ze stali zwykłej wytrzymałości, typu S235 (podgrupa 1.1).

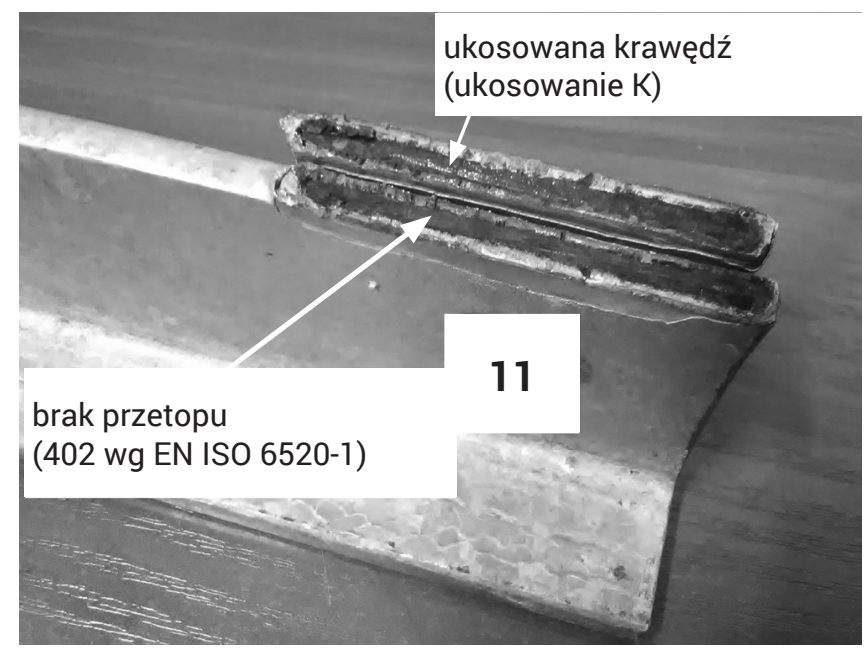

Rys. 6. Przełom złącza nr 11, ukosowanie na K brak przetopu 402 wg EN ISO 6520-1

Fig. 6. Fracture no. 11 (K-grove, lack of penetration 402 acc. to EN ISO 6520-1)

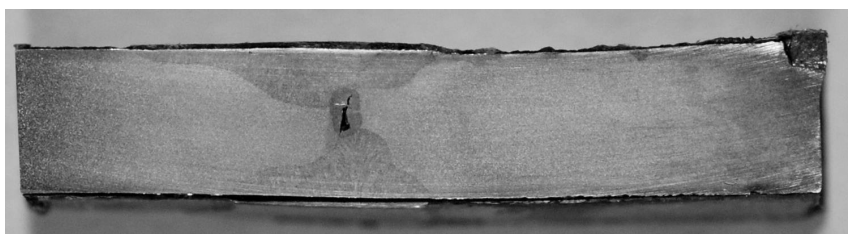

Rys. 7. Zgład makroskopowy złącza czołowego nr 12

Fig. 7. Macroscopic photo, weld joint No 12

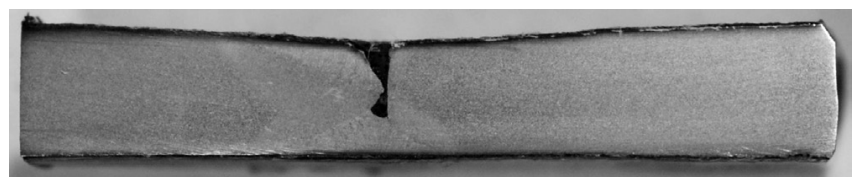

Rys. 8. Zgład makroskopowy złącza czołowego nr 23 Fig. 8. Macroscopic photo, weld joint No 23

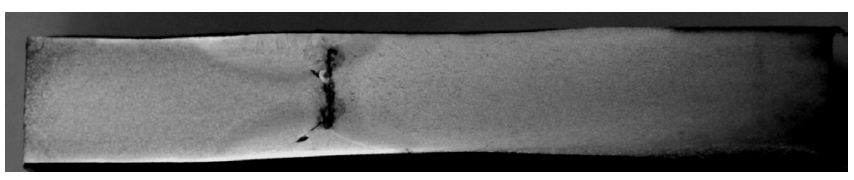

Rys. 9. Zgład makroskopowy złącza czołowego nr 34 Fig. 9. Macroscopic photo, weld joint No 34

\section{Propozycja zapewnienia poziomu jakości przez zamawiającego}

Jak wynika z przedstawionego materiału, dyrektywa maszynowa w swoim obecnym brzmieniu nie zapewnia wymaganej jakości wyrobu. Z pewnością jak się wydaje, wymaga pilnego uzupełnienia o system jakości w spawalnictwie, np. oparty o normę EN1090-2, ale to zapewne, z przyczyn proce-

Tablica I. Wyniki próby rozciągania próbek Table I. Results of tensile test

\begin{tabular}{|c|c|c|c|c|c|}
\hline $\mathrm{Nr}$ & $\begin{array}{l}\text { Próbka ze spoiną } \\
\text { o numerze }\end{array}$ & Wymiary a x b, mm & $\begin{array}{l}\text { Maksymalna siła } \\
\qquad \mathrm{F}_{\mathrm{m}, \mathrm{N}}\end{array}$ & $\begin{array}{c}\text { Wytrzymałość } \\
\text { na rozciąganie } R_{m}, M P a\end{array}$ & Uwagi \\
\hline 1 & 10 & $5,99 \times 36,70$ & 58270 & 265 & złom w spoinie \\
\hline 2 & 12 & $6,19 \times 36,05$ & 62200 & 279 & złom w spoinie \\
\hline 3 & 22 & $5,84 \times 29,33$ & 41080 & 240 & złom w spoinie \\
\hline 4 & 23 & $5,84 \times 32,49$ & 52210 & 276 & złom w spoinie \\
\hline 5 & 24 & $5,71 \times 32,20$ & 35950 & 196 & złom w spoinie \\
\hline 6 & 25 & $5,77 \times 26,50$ & 45180 & 295 & złom w spoinie \\
\hline 7 & 32 & $5,40 \times 28,93$ & 23990 & 154 & złom w spoinie \\
\hline 8 & 33 & $6,49 \times 31,85$ & 14830 & 72 & złom w spoinie \\
\hline 9 & 34 & $6,05 \times 32,95$ & 58610 & 294 & złom w spoinie \\
\hline 10 & 35 & $5,97 \times 30,64$ & 25720 & 141 & złom w spoinie \\
\hline 11 & 51 & $5,07 \times 23,04$ & 57940 & 496 & $\begin{array}{c}\text { złom w materiale, złącze naprawione, } \\
\text { poprawne }\end{array}$ \\
\hline
\end{tabular}


duralnych, będzie wydłużone w czasie. Dlatego warto wspomnieć o możliwościach innych, np. przez wprowadzenie w umowie specyfikacji konstrukcji - powszechnie praktykowanej w obszarze konstrukcji odpowiedzialnych i jak wynika z praktyki, skutecznych. Przykładowo taka specyfikacja może wyglądać następująco:

1) określenie norm i przepisów, jakie musi spełniać konstrukcja;

2) określenie poziomu jakości dla spoin i zakresu NDT spoin;

3) określenie wymagań dotyczących WPQR i WPS;

4) wymagania dotyczące materiałów podstawowych;

5) zakresu kontroli i zapisów dotyczących kontroli wyrobu;
6) wymagania dotyczące kwalifikacji personelu (nadzoru, spawaczy, NDT);

7) wymagania dotyczące zabezpieczenia przeciw korozji;

8) zawartość dokumentacji końcowej wyrobu.

Innym rozwiązaniem, również praktykowanym, jest wstawienie do umowy następującej klauzuli: „konstrukcja spawana maszyny ma być wykonana zgodnie z normą EN 1090-2".

Warto tu dodać, że rzetelnie wykonana i porządnie wydana dokumentacja zdawcza, poprawia wizerunek Wytwórcy, jest też ważnym atutem marketingowym, a jednocześnie ogranicza pole do nieuzasadnionych reklamacji, mniej uczciwych odbiorców, co niestety też ma miejsce!

\section{Wnioski}

1. Dyrektywa Maszynowa nie stawia żadnych wymagań jakościowych przy stosowaniu procesów spawalniczych.

2. Stan taki sprzyja produkcji skandalicznie niskiej jakości wyrobów maszynowych, stanowiących zagrożenie dla zdrowia, a nawet życia ludzkiego, co jasno wynika z przedstawionego zdarzenia.

3. Z przeprowadzonej ekspertyzy w sposób oczywisty wynika, że Wytwórca rzeczonej linii technologicznej, nie stosował żadnego systemu jakości, jak też końcowej kontroli i badań elementów spawanych, co wcale nie było przeszkodą w wystawieniu deklaracji zgodności wg dyrektywy maszynowej opatrzonej znakiem CE.

4. Wystawienie przez Wytwórcę deklaracji zgodności wg dyrektywy maszynowej opatrzonej znakiem CE nie podlega żadnej weryfikacji, więc może być nadużywane.

5. W tej sytuacji wydaje się celowe, pilne uzupełnienie owej dyrektywy o wymagania jakościowe dotyczące spawania, np. przez obligatoryjne stosowanie normy EN 1090-2 [2].

6. Z praktyki wynika, że całkiem skutecznym sposobem zapewnienia wymaganego poziomu jakości, są odpowiednie zapisy w umowie, np. w technicznych warunkach wykonania, przedstawione w postaci wskazania wymaganych norm lub podania specyfikacji wykonanej przez zamawiającego.

7. Rzetelnie wykonana i porządnie wydana dokumentacja zdawcza, poprawia wizerunek Wytwórcy, jest korzystna marketingowo, a jednocześnie ogranicza pole do nieuzasadnionych reklamacji, mniej uczciwych odbiorców, co niestety też ma miejsce!

8. Upór i odmowa przyjęcia oczywistej reklamacji, może skutkować utratą wizerunku, wiarygodności, dodatkowymi koszta$\mathrm{mi}$, a nawet utratą klienta.

\section{Literatura}

[1] Dyrektywa 2006/42/WE Parlamentu Europejskiego i Rady z dnia 14-052006 r. w sprawie maszyn, zmieniająca dyrektywę 95/16/WE.

[2] Norma EN 1090 - Wykonanie konstrukcji stalowych i aluminiowych.

[3] Norma EN 3834 - Wymagania jakości dotyczące spawania.

[4] Szczok E.: Wymagania jakościowe procesów spajania w oparciu o normę PN-EN ISO 3834: 2007; Materiały XIII Naukowo-Technicznej Konferencji: Postęp, innowacje i wymagania jakościowe procesów spajania, Międzyzdroje 29-31.05.2007.

[5] Saperski J.: Wpływ wprowadzenia normy PN-EN 1090 na spawalnictwo w małych wytwórniach konstrukcji spawanych, Materiały XX NaukowoTechnicznej: Konferencji Postęp, innowacje i wymagania jakościowe procesów spajania, Międzyzdroje 27-29.05.2014.

[6] Szubryt M., Wincza M.: Jakość handlowa. Czy jakość rzeczywista?, Materiały XIII Naukowo - Technicznej Konferencji: Postęp, innowacje i wymagania jakościowe procesów Spajania, Międzyzdroje 29-31.05.2007.
[7] Wincza M.: Analfabetyzm techniczny - rzeczywistość czy fikcja. Analiza problemu, Materiały XIV Naukowo-Technicznej Konferencji: Postęp, innowacje i wymagania jakościowe procesów spajania, Międzyzdroje 27-29.05.2008.

[8] Urbański M.: Spawanie wielkogabarytowych elementów wsporników (typ V) wałów śrubowych statków, Biuletyn Instytutu Spawalnictwa, nr 2, 2011.

[9] Saperski M.: Technologia spawania konstrukcji trzonu sterowego podczas remontu statku, Biuletyn Instytutu Spawalnictwa, nr 5, 2011.

[10] Saperski J.: Wymagania jakościowe konstrukcji offshore, Materiały XIV Naukowo-Technicznej Konferencji: Postęp, innowacje i wymagania jakościowe procesów Spajania, Międzyzdroje 27-29.05.2008.

[11] Saperski M.: Technologia spawania wielkogabarytowych pierścieni konstrukcji offshore, Biuletyn Instytutu Spawalnictwa nr 6, 2015.

[12] Pieńczuk A.: Personel spawalniczy oraz kontroli i badań. Zadania i odpowiedzialność w świetle wymagań normy serii EN ISO 3824, Spajanie Materiałów Konstrukcyjnych nr 4, 38, 2017. 